\title{
Średniowieczny miecz z Zyndranowej we wschodniej Małopolsce
}

Medieval Sword from Zyndranova in the Eastern Little Poland

\begin{abstract}
Abstrakt: W zbiorach Prywatnego Muzeum Zamkowego „Kamieniec” w Odrzykoniu przechowywany jest miecz odkryty przypadkowo w rzeczce Panna, przepływającej przez miejscowość Zyndranowa (woj. podkarpackie). Zachowany niemal w całości zabytek reprezentuje typ XVIa, I (ıa), Iı (ı b) w klasyfikacji R.E. Oakeshotta. Na mieczu znajdują się trzy znaki: w pobliżu nasady trzpienia wybito puncą znak kowalski w kształcie litery s, umieszczonej we wklęsłym polu, a po obu stronach głowni - naprzeciw siebie - umieszczono dwa różne znaki miecznicze,
\end{abstract}

inkrustowane żółtym metalem. Jeden z nich to znak rozwidlonego krzyża w podwójnym okręgu, z kolei drugi jest trudniejszy do interpretacji. Przypomina gotycką literę A, również zamkniętą w podwójnym okręgu, ale obecność pionowej kreski w domniemanej literze może wskazywać, iż mamy tutaj do czynienia $\mathrm{z}$ inną możliwością, np. kombinacją liter AA lub AR. Miecze analogiczne do okazu z Zyndranowej były powszechne na terenie Polski, głównie pomiędzy połową XIV a połową XV stulecia, z możliwością zawężenia tej chronologii do początków XV stulecia.

Słowa kluczowe: Królestwo Polskie, Małopolska, Przełęcz Dukielska, późne średniowiecze, miecz, znalezisko wodne

Niewielka wieśZ Zyndranowa (gm. Dukla, pow. krośnieński, woj. podkarpackie, PL) leży na północnych skłonach głównego grzbietu karpackiego, nad rzeczką Panna, lewym dopływem Jasiołki. W średniowieczu obszar, na którym założono wieś, należał do powiatu bieckiego województwa krakowskiego, sytuując się tuż przy granicy z ziemią sanocką województwa ruskiego. Początki wsi - pierwotnie zwanej Zyndramową - sąjednak niejasne, po raz pierwszy pojawia się w źródłach dopiero w I523 r. (Czajkowski 1995: I22-I23). Obszar ten miał jednak istotne znaczenie w późnym średniowieczu, leży bowiem tuż u północnego wylotu Przełęczy Dukielskiej, ważnego szlaku komunikacyjno-handlowego prowadzącego z Węgier na północ, w stronę Sandomierza i dalej ku Bałtykowi (por. Kurtyka 1996: 190-19I). Nie był to więc teren zupełnie opustoszały i omówione niżej znalezisko dobrze wpisuje się w ten obraz. 
Niedługo po roku 2000, w bliżej nieokreślonych okolicznościach, w nurcie wspomnianej rzeczki Panny w obrębie wsi Zyndranowa został odkryty średniowieczny miecz. Niestety, nie znamy dokładnego miejsca znaleziska, natomiast wiadomo, iż niedługo później trafiło ono w ręce kierownika nieodległego kamieniołomu Wietrzno-Rogi. Ostatecznie zabytek znalazł się w zbiorach Prywatnego Muzeum Zamkowego „Kamieniec” w Odrzykoniu, gdzie jest przechowywany pod numerem inwentarzowym $\mathrm{M} 27 / \mathrm{OI} / \mathrm{K}^{1}$.

Interesujący nas zabytek zachował się w stosunkowo dobrym stanie, chociaż brakuje mu znacznej części sztychu. Na jego powierzchni widać także ślady wywołane powierzchniową korozją, ale nie są one na tyle poważne, aby utrudniły analizę typologiczną. Obecna długość całkowita zabytku wynosi 99,0 cm, a sama głownia zachowała się do długości $76,0 \mathrm{~cm}$. Wnioskując z zachowanych w całości analogicznych okazów, możemy przypuszczać, że miecz z Zyndranowej mógł być pierwotnie dłuższy o około 20-25 cm (Głosek, Nadolski 1970: 50-51, kat. 59; Głosek 1984: 158, kat. 269; Aleksić 2007: 89; Glinianowicz, Kotowicz 2009: 184). Obecna masa zabytku wynosi $1328 \mathrm{~g}$, a środek ciężkości ulokowany jest na głowni, około 9,0 cm poniżej jelca. Należy jednak pamiętać, że pierwotnie broń ta ważyła nieco więcej, a punkt wyważenia był przesunięty w kierunku sztychu. Głownia jest smukła, szeroka w zastawie $(5,6 \mathrm{~cm})$ i stopniowo zwęża się ku sztychowi, a w miejscu ubytku ma szerokość $2,5 \mathrm{~cm}$. Na obydwu stronach głowni widoczne jest pojedyncze, płytkie zbrocze, mające swój początek jeszcze na trzpieniu rękojeści i sięgające do 49,5 cm poniżej jelca. Szerokość tego elementu wynosi około I, $5 \mathrm{~cm}$ na zastawie i zwęża się w kierunku sztychu, do około $0,5 \mathrm{~cm}$ na jego końcu. Głownia w przekroju ma formę soczewkowatą o grubości od o,7 cm w zastawie do około 0,5 cm w miejscu, gdzie kończy się zbrocze. Trzpień rękojeści ma formę prostokątnej w przekroju sztabki o wymiarach $0,8 \times 2,4 \mathrm{~cm}$ przy jelcu i o, $8 \times \mathrm{I}, 4 \mathrm{~cm}$ przy głowicy. Jego długość wynosi $22,0 \mathrm{~cm}$, a zaklepany od góry koniec przechodzi przez całą głowicę.

Jelec miecza z Zyndranowej wykonano z czworobocznego w przekroju pręta ze zgrubieniem i otworem służącym do osadzenia na głowni, w środkowej jego części. Ramiona zostały łagodnie wygięte w kierunku głowni, nadając całości nieznacznie łukowaty kształt. Jego długość wynosi $22,5 \mathrm{~cm}$, a przekrój $0,7 \times 0,9 \mathrm{~cm}$. Głębokość ugięcia łuku jelca wynosi I,o cm.

1 Autorzy składają serdeczne podziękowania Panu Andrzejowi Kołderowi, organizatorowi muzeum na zamku „Kamieniec”, za udostępnienie miecza do opracowania, a także koledze Robertowi Fedykowi za dodatkowe informacje o znalezisku. 


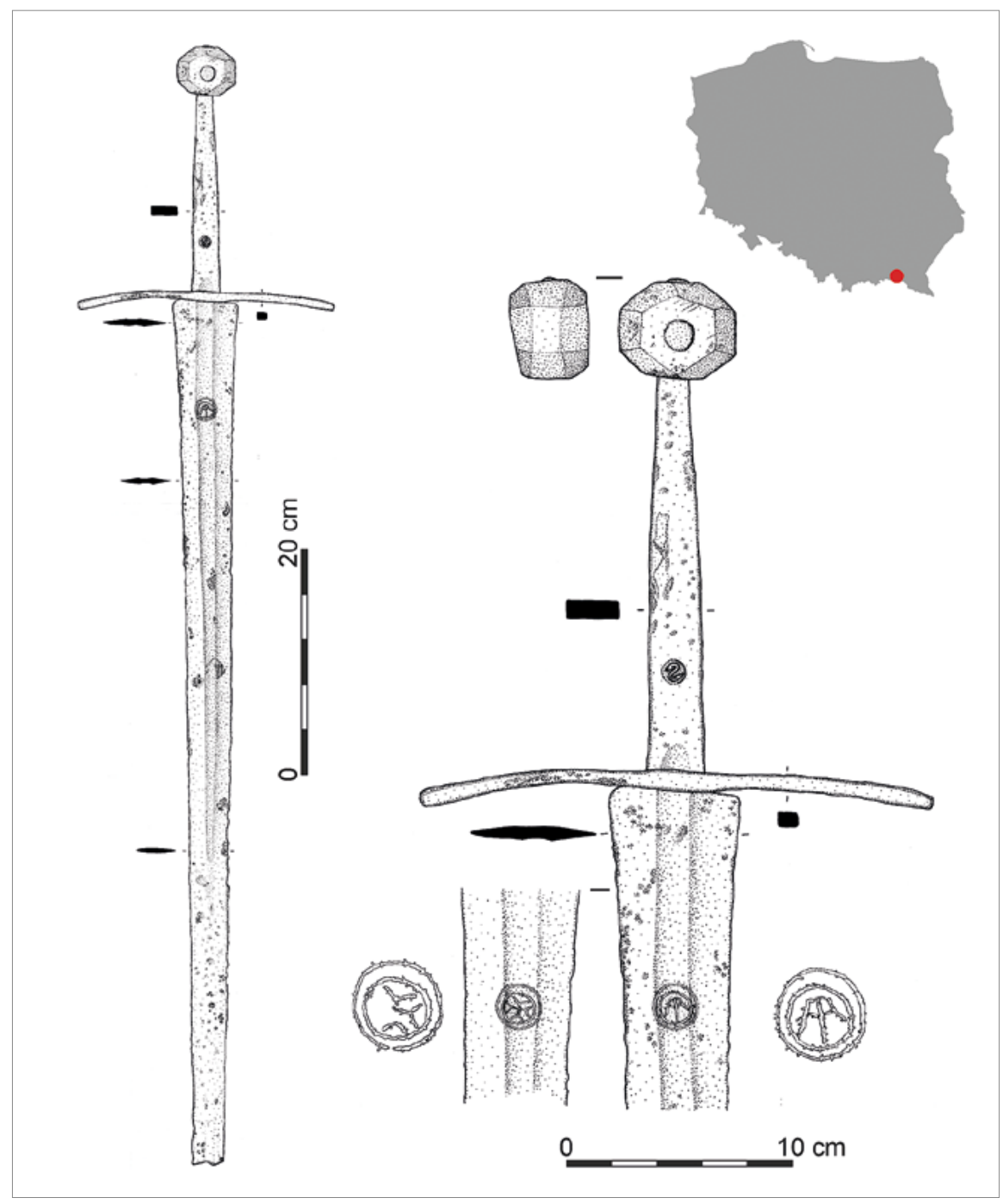

Ryc.1. Miecz z Zyndranowej, pow. krośnieński, woj. podkarpackie (rys. P.N. Kotowicz; przerys A. Sabat).

Masywna głowica ma formę wielościenną. Dwie powierzchnie, zgodne z płazami głowni, są heksagonalne i mają takie same wymiary - wysokość 3,5 cm oraz szerokość $3,4 \mathrm{~cm}$. Na środku tych sześciokątnych boków wykonano okrągłe wgłębienia o średnicy $\mathrm{I}, 3 \mathrm{~cm}$. Zewnętrzny zarys głowicy ma formę oktagonalną, o wysokości 4,3 cm i szerokości 5,2 cm. Grubość tej części miecza wynosi 3,5 cm.

Interpretacja typologiczna poszczególnych elementów składowych omawianego tu zabytku nie nastręcza poważniejszych kłopotów. 


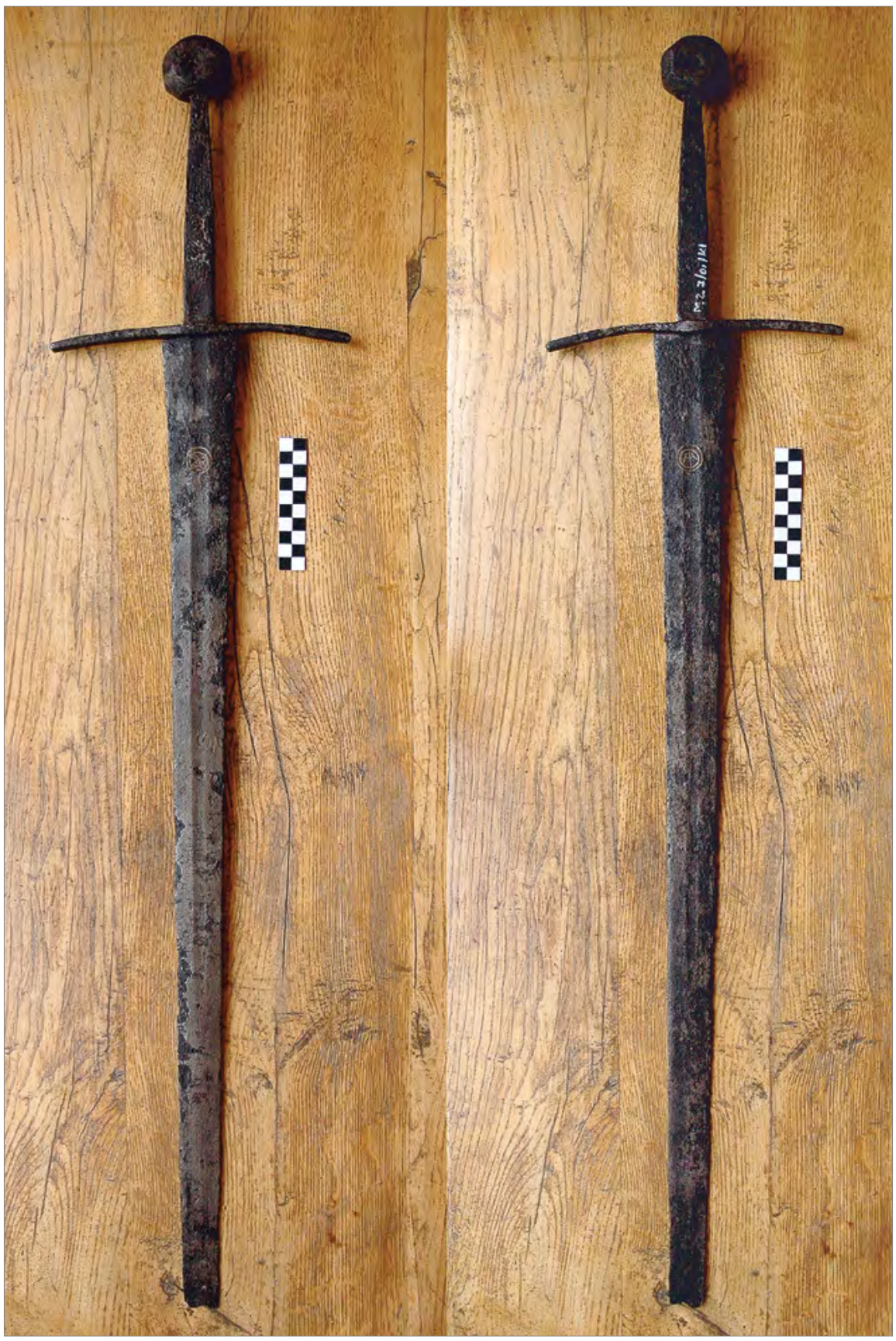

Ryc. 2. Miecz z Zyndranowej, pow. krośnieński, woj. podkarpackie (fot. M. Glinianowicz). 
Smukła, długa głownia, z wyraźnie zarysowanym, pojedynczym zbroczem i oburęczną rękojeścią, bez wątpienia reprezentuje typ XVIa w systematyce Ronalda E. Oakeshotta (1964: 63-65). Głownia omawianego przez nas zabytku jest niestety uszkodzona, ale na podstawie cech charakterystycznych można domniemywać, że zwężał się on równomiernie ku wąskiemu, kończystemu sztychowi. Nadawało to broni z tej grupy bardzo pożądanych cech uniwersalnych. Stosunkowo wąska głownia mogła z powodzeniem służyć zbrojnemu, zarówno do zadawania cięć, jak i pchnięć, zwłaszcza ta druga technika zapewniała lepsze powodzenie w przypadku walki z przeciwnikiem zabezpieczonym rozwijającymi się ówcześnie elementami płytowymi zbroi. Nie dziwi więc bardzo duża frekwencja typu XVIa wśród mieczy pochodzących z terenów Królestwa Polskiego, ale także państw sąsiednich. Fakt ten zaobserwowany został już przez Mariana Głoska, w którego katalogu liczy on I3I zabytków, czyli około 40\% wszystkich egzemplarzy (Głosek 1984: 137-177). Nowsze znaleziska potwierdzają te obserwacje (por. np. Szope 1985: kat. II; Polakiewicz 1994: 425; Liwoch 2006: 33-37; Marek 2008: 72-73; Glinianowicz, Kotowicz 2009: 182-197; Kuśnierz 2010: 215-218; Kotowicz, Glinianowicz 20II: 20I-2I8; Pudło, Żabiński 20II: 30-3I; Krzyszowski i in. 20r4; Żabiński i in. 2014: 68).

R.E. Oakeshott, który traktuje głownie w typie Xvia jako formę ewolucyjną typu XIIIa, umieszczał je generalnie w końcu XIV i początkach XV w., choć dostrzegał ich wyraźne cechy już u progu XIV stulecia (Oakeshott 1964: 63-65; por. Marek 2008: 72; 2014: 57-58, przyp. 42). Konkluzje te zostały nieco zmodyfikowane w toku kolejnych analiz. Obecnie wiemy, iż głownie takie były znacznie dłużej w użyciu - trwają z pewnością do końca XV (Głosek 1984: 29-30, kat. 38; Aleksić 2007: 89; Krzyszowski i in. 2014: 174-175; Żabiński i in. 2014: 68; Hošek $\mathrm{i}$ in. 2019: kat. 13, 30, 37, I42, 174, 320, 332, 34I, 42I), a nawet pierwszej połowy XVI w. (Hošek i in. 2019: kat. 237, 277, 282, 287, 298, 318, 419).

Przy klasyfikowaniu jelca występującego przy mieczu z Zyndranowej warto skorzystać z modyfikacji, jaką do typologii R.E. Oakeshotta wprowadził M. Głosek (1984: 39). Okazy cechujące się lekkim ugięciem ramion w kierunku głowni polski bronioznawca umieścił w podtypie ra. Jelce w stylu I (wraz z podtypem ra) nie wykazują wyraźnych zmienności cech w całej rozciągłości wieków średnich (Oakeshott 1964: I13) i ich przydatność dla datowania konkretnych egzemplarzy mieczy jest znikoma.

2 Wcześniejsze występowanie takich głowni mógłby teoretycznie potwierdzać okaz o nieustalonym miejscu odkrycia przechowywany w czeskim Křivokláte (Národní památkový ústav - Státní hrad Křivoklát), który zaopatrzony jest w głowicę typu в. W tym przypadku mamy jednak do czynienia z sytuacją, w której do nowej głowni dodano starszy typ głowicy (Hošek i in. 2019: kat. 324). 


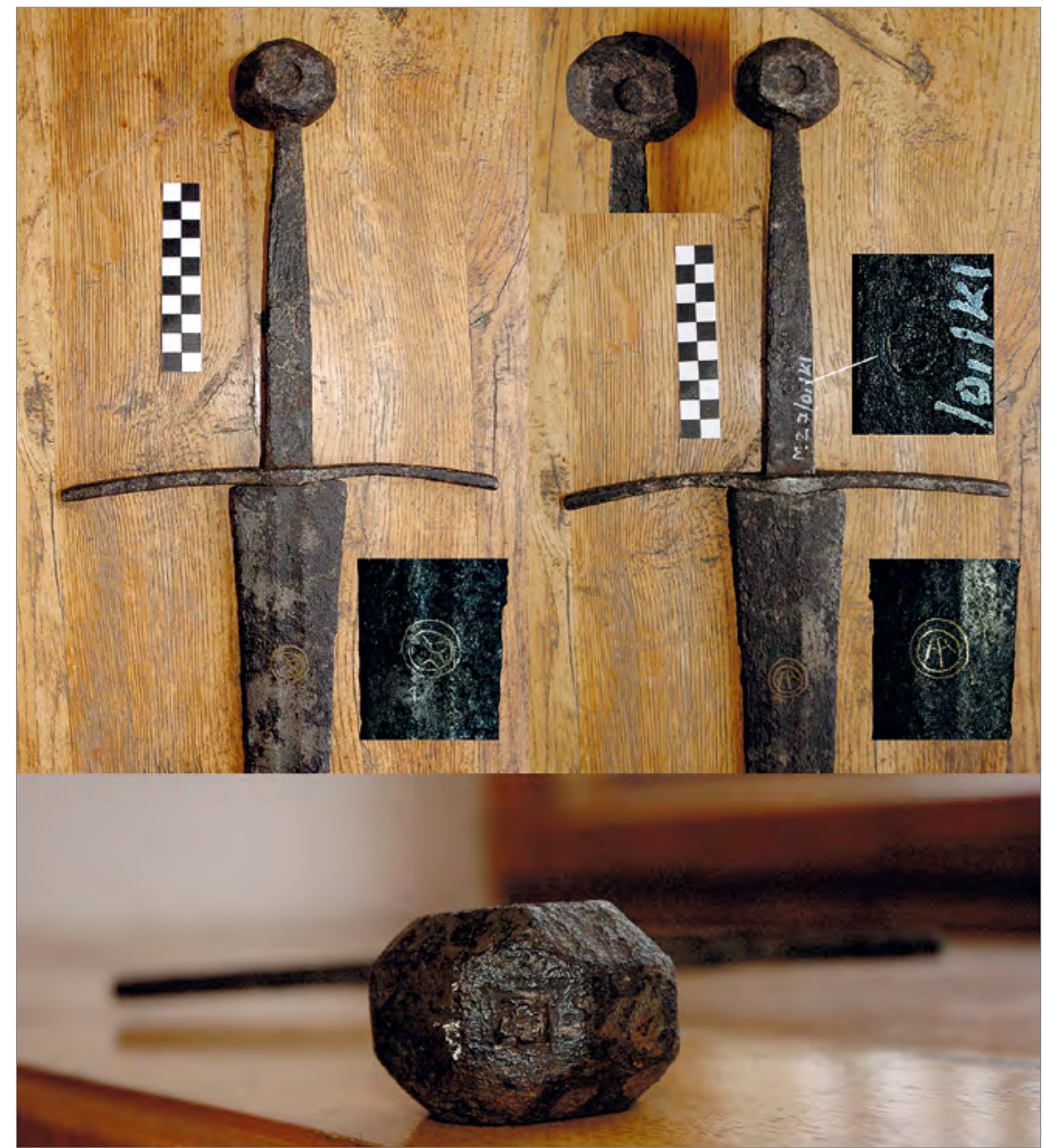

Ryc. 3. Detale miecza z Zyndranowej, pow. krośnieński, woj. podkarpackie (fot. M. Glinianowicz).

Oktagonalną, masywną głowicę miecza z Zyndranowej należy uznać za egzemplarz podtypu $\mathrm{I}_{1}$, należącego do jednej z bardziej popularnych form zwieńczeń mieczy w późnym średniowieczu niemal w całej Europie (por. Michalak 2019: 88; patrz też Aleksić 2007: 52-53; Pudło, Żabiński 2011: 30-31; Hošek i in. 2019: kat. 2, II, 64, 2I2, 253, 273, 275, 278, 294, 306, 348, 360, 388, 403). Warto jednak zaznaczyć, iż wieloboczne głowice stanowiły niekiedy też oprawy innych niż miecze rodzajów broni białej. Za przykład posłużyć tutaj może datowany na XIV stulecie tasak o częściowo ułamanej głowni ze zbiorów Koninklijk Museum van het Leger en de Krijgsgeschidenis w Brukseli, zaopatrzony w taką właśnie, brązową głowicę 
(Michalak 2007: 203; Žákovský 2011: 84I, Fig. 254:d). Niekiedy też głowice tego typu były wtórnie wykorzystywane jako bijaki cepów bojowych. Świadczą o tym XIV-XV-wieczne zabytki odkryte na terenie Republiki Czeskiej - jeden z nich nie ma określonego miejsca odkrycia, na drugi natrafiono przypadkowo w Táborze. Oba zabytki zostały zaopatrzone w okrągłe uszka połączone z pojedynczym ogniwem łańcucha (Hošek i in. 2019: kat. 236, 396).

Wracając jednak do głowic mieczowych, przyjrzyjmy się bliżej kontrowersjom dotyczącym początków ich wytwarzania. R.E. Oakeshott uważał - bazując na licznych wyobrażeniach na zachodnioeuropejskich nagrobkach rycerskich - iż głowice tego typu najpopularniejsze były od około I360 do I440-I450 r. (Oakeshott I964: IO3). Datowanie to podtrzymał ostatnio Marco Aleksić, chociaż wspomniał, iż sporadycznie pojawiają się już wcześniej (Aleksić 2007: 5I). Badacze ci skłonni są przyjąć, iż najstarszy okaz miecza z taką głowicą i napisem BENEDICTUS na głowni odkryty został w pochówku w miejscowości Liuksiala w Finlandii, datowanym już na około IIoo r. (Oakeshott 1991: 39, iv; Aleksić 2007: 51-52), ale bliższe przyjrzenie się zwyczajom pogrzebowym na terenie Finlandii w późnych fazach wczesnego średniowiecza rodzi wiele wątpliwości co do poprawności takiego datowania (por. Michalak 2019: 88). Nie spotkała się również z akceptacją teza, iż głowica taka została wyobrażona na nagrobku króla Anglii Ryszarda Lwie Serce, znajdującym się w opactwie w Fontevrault we Francji i datowanym na początek XIII w. ${ }^{3}$ (Zdaniewicz 20II: 499; krytycznie Marek 20I4: 52; Michalak 2019: 88). Jednym z najstarszych zabytków tego typu jest zatem wykonana z brązu głowica odkryta w kontekście stratygraficznym z trzeciej ćwierci XIII stulecia na terenie Starego Miasta w Elblągu (Marek 20I4: 51, ryc. 19:b). Być może jeszcze wcześniejszą metrykę ma okaz odkryty na terenie grodu kasztelańskiego w Bytomiu Odrzańskim, funkcjonującego od połowy XI do połowy XIII w., który wystąpił w warstwie datowanej na schyłek jego funkcjonowania (Zdaniewicz 20I1: 497; Michalak 2019: 88). Z drugiej strony w warstwie tej natrafiono również na zabytki o zdecydowanie późniejszej, XV-wiecznej chronologii (Marek 20I4: 52). Wczesnym okazem, datowanym kontekstem archeologicznym na drugą połowę XIII i pierwszą połowę XIV stulecia, jest też głowica odkryta w Pyskowicach, pow. gliwicki (Zdaniewicz 20II: 496-497, ryc. r:2). Należy jednak zgodzić się z twierdzeniem, iż podobne okazy popularyzują się rzeczywiście dopiero w XIV i pierwszej połowie XV stulecia, a na terenie Polski towarzyszą głównie głowniom typu XIIIa i Xvia według Oakeshotta o dwuręcznych rękojeściach (por. Pudło, Żabiński 20II: 3I).

3 Nie można się również zgodzić z M. Aleksićem, iż z głowicą tego typu mamy do czynienia w przypadku okazu z miecza odkrytego w okolicach Preslavia w Bułgarii, datowanego na początki XIII w. (Aleksić 2007: 52, Pl. 5:I). W tym przypadku mamy do czynienia z okazem typu G3 wyróżnionym przez Mariana Głoska (1984:34-35, ryc.3). 
Stosunkowo często też (Kotowicz, Glinianowicz 20II: 205 - tam wcześniejsza literatura; por. też Hošek i in. 2019: kat. 2, 90, 273, 275, 278, 294, 396; Michalak 2019: 88-89), niemal już od początku występowania, na głowicach tego podtypu pojawiają się okrągłe, wykonane puncą wgłębienia, które dały M. Aleksićowi asumpt do wydzielenia odmiany $\mathrm{I}_{\mathbf{1}} \mathbf{b}$ (Aleksić 2007: 23). R.E. Oakeshott uważał, iż przynajmniej część z nich mogła stanowić miejsce, w którym mocowano monety, kolorowe metale czy drogocenne kamienie (por. Oakeshott 1991: III, I38, I85; Michalak 2019: 89).

W pobliżu nasady trzpienia rękojeści jednej ze stron miecza z Zyndranowej znajduje się znak kowalski. Jest to wykonane na gorąco owalną puncą płytkie wgłębienie o wymiarach $\mathrm{I}, 0 \times \mathrm{I}, 2 \mathrm{~cm}$, w którym znajduje się wypukła, odwrócona litera „s" z wyraźnie zaznaczonymi szeryfami.

Jakkolwiek zwyczaj umieszczania znaków kowalskich w tym miejscu sięga jeszcze czasów Cesarstwa Rzymskiego ${ }^{4}$, to w średniowieczu spopularyzowały się dopiero w drugiej połowie XIII stulecia (Głosek 1973a: 325), choć incydentalnie występowały już wcześniej, na co wskazuje znalezisko fragmentu miecza typu Xa (?), B, I, Z Voilovicy-Pančeva (Serbia), datowanego na drugą połowę XII i pierwszą połowę XIII w. (Aleksić 2007: II8, cat. 228, Fig. 6). Występują na mieczach aż do końca późnego średniowiecza, a nawet w początkach XVI w. (Žákovský 2008: obr. 5; Hošek i in. 2019: kat. 285).

Kowale sygnowali swe wyroby w różnoraki sposób, w tym również znakami analogicznymi do umieszczonego na mieczu z Zyndranowej. Identyczna, odwrócona litera „s” z szeryfami w okręgu umieszczona została na trzpieniu XIV-wiecznego miecza o głowni typu Xvia ze zbiorów Muzeum Narodowego we Wrocławiu (ryc. 4: 2), którego proweniencję M. Głosek ostrożnie wiązał z niezidentyfikowanym warsztatem niemieckim (Głosek 1973b: 16, kat. 75, tabl. XXXVI:I; 1984: 49, kat. 4I3, tabl. I:413). Taka sama sygnatura zdobi również jeden z mieczy odkrytych w trakcie badań archeologicznych zamku w Ciechanowie, pow. loco (ryc. 4: 3). Znaleziono go wraz z innymi militariami (żeleźcem topora, głowicą buławy i ostrogą) w fosie zamkowej i w momencie odkrycia na jego trzpieniu znajdowała się zachowana okładzina wykonana z drewna topoli

4 Przykłady takie znamy również z terenu Podkarpacia. Prostokątna punca kowalska została umieszczona na mieczu prowincjonalnorzymskim odkrytym w ciałopalnym pochówku (nr I6) kultury przeworskiej na cmentarzysku w Prusieku, pow. sanocki (stan. 25), datowanym na koniec starszego i początek młodszego okresu wpływów rzymskich (por. Madyda-Legutko i in. 2007: 64, ryc. 4). 


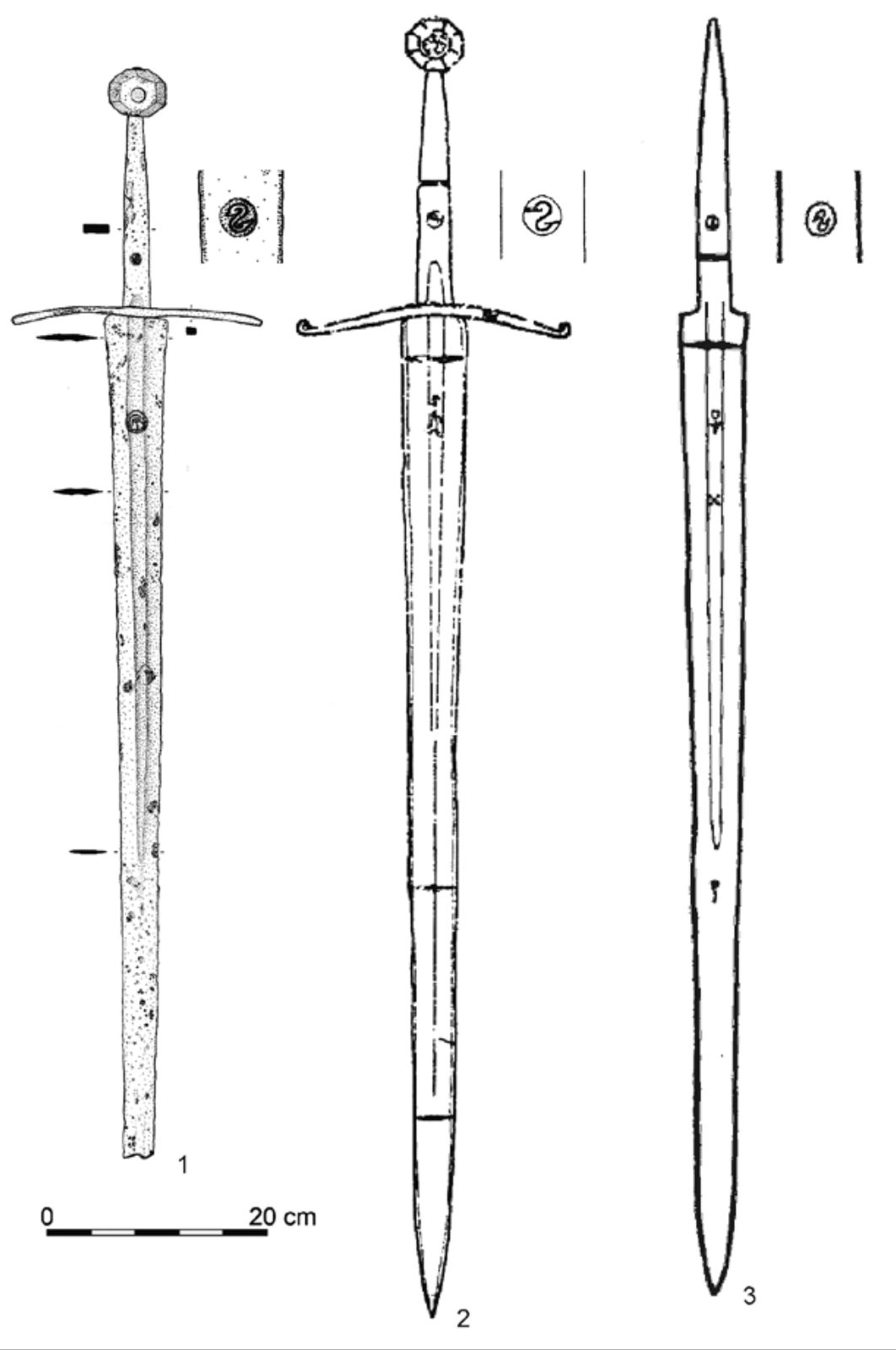

Ryc.4. Porównanie mieczy zaopatrzonych w identyczne znaki kowalskie (litera „s” w okręgu) na trzpieniach: I - Zyndranowa (rys. P.N. Kotowicz; przerys A. Sabat); 2- Ciechanów (według Małowiecki 1989: 132); 3 - Muzeum Narodowe we Wrocławiu (według Głosek i973b: kat. 75, tabl. xxxvi:I). 
pokryta skórą zszytą na zewnątrz i oplecioną drutem. Miecz zaopatrzony był również w skórzaną taszkę przykrywającą jelec. W publikacji źródłowej został on sklasyfikowany jako typ XVIa/XX, H2/II, Ib i wydatowany na drugą połowę XIV w. Przedstawienia wilka i litery „s” na głowni miecza zasugerowały autorowi jego południowoniemieckie pochodzenie. Fakt, iż analogicznie ukazane litery (choć wykonane innymi technikami) wystąpiły zarówno na trzpieniu, jak i głowni miecza pozwolił również na wysunięcie hipotezy, iż miecz ten wykonano w całości w jednym warsztacie (Małowiecki 1989: 130-I34). Nieco inaczej odniósł się do jego datowania M. Głosek, który uznał zabytek za egzemplarz typu typ XX, I2, Ib i datował na połowę XV w. (Głosek 1984: kat. 233). Swój osąd chronologiczny - oparty na racjonalnych przesłankach (moment wykopania fosy zamkowej) - podtrzymał przy okazji prezentacji głowicy buławy z Ciechanowa, sugerując, iż militaria tu odkryte należy datować na pierwszą połowę XV stulecia (Głosek 1996: 55-56).

Pozostałe znane znaki kowalskie zawierające literę „s" mają bardziej uproszczone formy. I tak, u nasady trzpienia fragmentarycznie zachowanego miecza o nieustalonym pochodzeniu typu XVII, TI/T2 ze zbiorów Muzeum Archeologicznego Środkowego Nadodrza w Zielonej Górze (z siedzibą w Świdnicy), datowanego na drugą połowę XIV i początki XV stulecia, w trakcie prześwietleń rentgenowskich ujawniono dwa znaki. Obok szczątkowo zachowanej sygnatury o nieokreślonym bliżej kształcie widoczny jest znak w postaci owalnej obwódki, wewnątrz której znajduje się litera "s” o ramionach zaopatrzonych w krótkie prostopadłe linie (Michalak 2019: 89-90, kat. 44, tabl. 38:8-10). Również i ten miecz wiązany jest hipotetycznie z warsztatami niemieckimi (Michalak 2019: 90). Z kolei na trzpieniu miecza typu XIV, J, 3 ze zbiorów Muzeum Wojska Polskiego $\mathrm{w}$ Warszawie, datowanego na drugą połowę XIII i pierwszą połowę XIV stulecia, wystąpił wykonany sztancą (wklęsły) znak odwróconej litery „»”, pozbawionej dodatkowych ozdobników (Głosek 1973b: 16, kat. 80, tabl. xx:I).

Po obu stronach głowni miecza z Zyndranowej, w odległości 8,5 cm od jelca - naprzeciw siebie - umieszczono dwa różne znaki wykonane techniką inkrustacji kolorowym metalem.

Jeden z nich, nieznacznie uszkodzony, to znak rozwidlonego krzyża (ang. cross fourchée) zamknięty w dwóch okręgach. Znak ten, występujący w kilku wariantach - w pojedynczym lub zdwojonym okręgu oraz bez tych dodatkowych elementów - jest jednym z najpopularniejszych rodzajów krzyża wyobrażanych na mieczach europejskich (Głosek 1973a: 329; 1984: 55; Aleksić 2007: 122; Żabiński 2017: 169; Hošek i in. 2019: passim). 
W starszej literaturze pojawiła się hipoteza, iż znaki te są być może markami warsztatów mieczniczych. Wendelin Boeheim sugerował na przykład, iż wariant tego znaku w podwójnej obwódce wraz z towarzyszącą mu sygnaturą w postaci prostej kreski zakończonej rozwidlonymi ramionami i przeciętą dodatkową ukośną kreską (obie inkrustowane złotem) należy wiązać z XIII-wiecznymi pracowniami saraceńskimi. $Z$ kolei znak takiego krzyża w pojedynczej obwódce wiązał Z warsztatami włoskimi i datował na XIII-XV w. (Boeheim I890: 674). Na potwierdzenie swych słów nie podał jednak żadnych argumentów (por. Głosek 1984: 55). Z kolei M. Głosek przypuszczał, iż znaczna liczba mieczy sygnowanych tym znakiem odkrytych na terenie ziem polskich wskazywać może, iż posługiwały się nim lokalne pracownie miecznicze, niekoniecznie zaś jeden ośrodek (Głosek 1973a: 329). Warto też zwrócić uwagę na ustalenia Davida G. Alexandra, który, omawiając miecze z dawnego arsenału aleksandryjskiego, uznał, że okazy z interesującymi nas znakami należy uznać za wytwory pracowni niemieckich (Alexander 1985:90).

Czy jednak rzeczywiście znak ten utożsamiać należy jednoznacznie jako markę warsztatu lub warsztatów rzemieślniczych? Warto zauważyć, iż w kilku (jak dotąd) przypadkach stwierdzono ich współwystępowanie z marką przypisywaną jednoznacznie pracowni mieczniczej. Chodzi o miecze ze zbiorów niemieckich, czeskich, okaz z ratusza w Tarnowie oraz zabytek z arsenału w Aleksandrii (obecnie zbiory Askeri Museum w Stambule) ze znakami w kształcie wilka, które uznaje się za sygnatury pracowni niemieckiej w Pasawie, a później również w Solingen i innych, ale też warsztatów węgierskich (Głosek 1984: 55; Alexander 1985: 84, nr 8; Szope 1985: kat. 8; Žákovský 2008: 483-484, obr. I:b i II; Hošek i in. 2019: kat. 52 i 285; na temat znaków wilka por. też Marek 2014: 58-59; Żabiński i in. 20I4: I22-I27). W tych przypadkach trudno znaki rozwidlonego krzyża uznać za marki wytwórców.

Przeczyć temu może również analiza przykładów takich symboli stanowiących elementy dłuższych inskrypcji, w których występują z reguły na początku lub końcu napisu (np. Anteins 1966: II8, I19, Abb. 4:4, 5:3; Głosek 1984: tabl. III:II, VIII:I45,I49, X:I83). W tych przypadkach mają one charakter zdobniczy, stanowiąc dopełnienie kompozycji inskrypcji (Głosek, Kajzer 1976: 223; Głosek 1984: IIO, II7). Jeszcze inną rolę - naszym zdaniem najbardziej prawdopodobną - podobnym znakom przypisali badacze (M. Głosek i L. Kajzer), omawiając grupę mieczy $\mathrm{z}$ napisem DIC. Zasugerowali oni iż znaki te spetniaty [...] raczej rolę znaku ideograficznego, przenoszac uwage użytkownika ku ogólniejszym pojęciom zwiąanym z religia chrześcijańska (Chrystus, cierpienie, zbawienie) (Głosek, Kajzer 1976: 223). Dodatkowo znak taki mógł stanowić rodzaj niematerialnej zbroi, chroniącej duszę wojownika przed pokusami (Marek 2017: 100). Wydaje nam się, iż ze względu na popularność symbolu rozwidlonego krzyża na mieczach, jego interpretacja jako znaku religijnego jest najbardziej właściwa (por. Oakeshott 2000: 8I). 
Marian Głosek słusznie zauważył wewnętrzne zróżnicowanie znaków rozwidlonego krzyża, które może być odbiciem jego rozwoju. Najprostsze są znaki, gdzie występuje sam krzyż, jego bardziej rozwiniętą formę stanowi krzyż w pojedynczym okręgu, a następnie znak, który widnieje też na mieczu z Zyndranowej, czyli krzyż obwiedziony dwoma okręgami ${ }^{5}$. Badacz ten stwierdził jednocześnie, iż różnorodność ta nie ma jednak charakteru ewolucyjnego (Głosek 1973a: 7I).

Aktualny stan badań może sugerować, iż tezę tę należałoby nieco zmodyfikować. Wydaje się bowiem, iż rozwidlone krzyże pozbawione obwódki pojawiają się jednak nieco wcześniej, aniżeli pozostałe ich rodzaje. Wskazuje na to chociażby przykład miecza z Pasilciems na Łotwie z dwoma napisami zaopatrzonymi w takie krzyże, datowanego na XI w. (Anteins I966: Tab. v). Jak się jednak wydaje, znak taki upowszechnia się dopiero po połowie XIII stulecia (por. Głosek 1984: kat. I49, I83, 459, tabl. VIII:I 49, X:I83, XVIII:459) i trwa przynajmniej do połowy XV w. (Głosek 1984: kat. 20, tabl. III:20; Alexander 1985: 86, nr 26; Aleksić 2007: kat. 268, pl. 6:2). Sporadycznie znaków takich używano też później, o czym świadczy okazały, ceremonialny, dwuręczny miecz ze zbiorów stambulskich, z analogicznym symbolem i wyobrażonymi herbami, które David Alexander wiąże z węgierską rodziną królewską Hunyadich - przede wszystkim królem Maciejem Korwinem, a także jego poprzednikiem Władysławem Pogrobowcem. Autor ten przypuszcza, iż miecz ten mógł znaleźć się w Stambule po zdobyciu Budy w 1526 r. (Alexander 1987: 22, 44: $\mathrm{nr} 76$ ).

Krzyże zaopatrzone w pojedynczy okrąg - które stanowią najpopularniejszą wersję tego znaku - występują na mieczach już od około połowy XII stulecia, na co wskazywać może egzemplarz typu xıa znaleziony w okolicach Pontirolo w północnych Włoszech. W tym przypadku znak w okręgu został dodatkowo zwieńczony analogicznym krzyżem pozbawionym obwódki (Oakeshott 2000: 81-82, Fig. 73). Podobnie jak poprzednia wersja, ta wersja znaku pojawia się częściej dopiero od drugiej połowy XIII stulecia, na co wskazuje znalezisko z Murchlina w Niemczech (por. Głosek 1984: kat. I49, tabl. viII:I49), czy datowany na przełom XIII i XIV stulecia okaz typu XIIIa, II, I, przechowywany w Muzeum w Nysie (Głosek 1984: kat. 280, tabl. XIII:280; Marek 2008: 71, ryc. 86:d). Na terenie Europy Środkowej popularyzują się głównie w XIV w. Popularne są też w kolejnym stuleciu, występując $\mathrm{z}$ reguły z różnymi wariantami głowic typu $\mathrm{Z}$ według R.E. Oakeshotta $\mathrm{z}$ uzupełnieniami M. Aleksića. Odkrywane są one jednak do tej pory jedynie na obszarach położonych na południe od Karpat i Sudetów (por. np. Głosek 1984: kat. 439, 483-485, tabl. XVII:439, XIX:483-484; Oakeshott 1991: 208, kat. XX.I; Aleksić

5 Nie wydaje się natomiast słuszne uznanie przez M. Głoska za rozbudowany znak rozwidlonego krzyża symbolu wyobrażonego na mieczu z Opatówka, pow. kaliski (por. Głosek 1973a: 7I). 
2007: kat. 121-123; Hošek i in. 2019: kat. 344). Taki symbol zdobi również głownię miecza o nietypowej formie odkrytego w Brandýsie nad Labem (Republika Czeska) i datowanego na XVI w. (Hošek i in. 2019: kat. IO). Potwierdzeniem przeżywania się takich znaków w tym stuleciu jest też miecz typu Xvıa(?), ?, I8, o nieustalonym pochodzeniu, przechowywany w zbiorach Muzeum Města Brna, którego chronologia określana jest na pierwszą połowę XVI stulecia (Hošek i in. 2019: kat. 282).

Miecze ze znakami rozwidlonego krzyża obwiedzionego dwoma okręgami - jak w przypadku omawianego tutaj miecza z Zyndranowej - są najrzadszymi egzemplarzami wśród znanych okazów z tym symbolem. Znane analogie zdają się też raczej świadczyć, iż zdobiono nimi głownie mieczowe wytwarzane znacznie później niż w przypadku znaków omówionych wyżej. Na drugą połowę XIV i pierwszą połowę XV w. datowany jest miecz typu XIIIa, Z2c, 6/12a? odkryty w okolicach Šabac w Serbii (Aleksić 2007: kat. 266, Fig. 35, Pl. 6:4). W drugiej połowie XIV w. został również wykonany miecz z arsenału w Aleksandrii (obecnie Askeri Museum w Istambule), który trafil do niego przed I 408 r. (Alexander 1985: 84, $\mathrm{nr} 8$ ). $\mathrm{Na}$ okres przed $\mathrm{I} 427 \mathrm{r}$. datowany jest kolejny okaz z arsenału aleksandyjskiego (Alexander 1985: 85, $\mathrm{nr}$ I2), a generalnie z pierwszą połową XV w. wiązane są miecze, z których jeden pochodzi z Belin w Rumunii (typ xıIIa/XVIa, H, I; por. Bordi 2008: 245, II. Tábla), a drugi jest przechowywany w Heimatmuseum w Demmin, Niemcy (typ xVIa, z, 5; por. Głosek I984: kat. 208, tabl. XII:208). Najmłodszy okaz, datowany na około drugą połowę XV w., znajduje się w zbiorach Vojni muzeja w Belgradzie (typ xıIIa, Ira, I2b; Aleksić 2007: Cat. 269, Pl. 17:4). Znak taki zdobi również bliżej nie datowaną głownię mieczową ze zbiorów Askeri Museum w Istambule (nr inw. 2367) (Alexander 1985: 94).

Znacznie więcej problemów przysparza interpretacja znaku (?) umieszczonego w podwójnym okręgu z drugiej strony głowni. Przypomina on gotycką literę „A”, przy czym, w odróżnieniu od większości znanych również z mieczy wyobrażeń tej litery, znak na mieczu z Zyndranowej ma dodatkową, pionową kreskę w środku. Jak dotąd autorom nie udało się natrafić na analogiczne przedstawienie w literaturze przedmiotu poświęconej średniowiecznym mieczom. Aktualnie nie sposób rozstrzygnąć jednoznacznie czy mamy tutaj do czynienia z bliżej nierozpoznanym symbolem, monogramem (litera A?), czy też może ligaturą dwóch liter (np. AA, AR). Zagadnienie to wymaga dalszych badań podjętych przez odpowiednich specjalistów z zakresu paleografii.

Miecz z Zyndranowej reprezentuje popularną na terenie Polski formę miecza. Wśród opublikowanych zabytków znamy co najmniej kilkanaście egzemplarzy, których charakterystyka odpowiada w całości omawianemu okazowi, a więc 
reprezentują typ XVIa, $\mathrm{I}_{\mathbf{1}}\left(\mathrm{I}_{\mathbf{1}} \mathbf{b}\right)$, I (Ia) w klasyfikacji R.E. Oakeshotta (z uzupełnieniami M. Aleksiča). Tylko jeden z nich odkryto jako część większego zespołu (?). Chodzi o miecz z Krakowa-Rakowic, pow. krakowski, który wydobyto wraz ze szczątkami ludzkimi oraz dwoma żeleźcami toporów, dwoma puginałami nożowatymi i dwoma innymi nożami, ostrogą, dwoma podkowami, trzema świdrami oraz innymi drobnymi przedmiotami żelaznymi i ułamkami ceramiki późnośredniowiecznej. Zbiór ten datowany jest na drugą połowę XIV - początek XV stulecia (Liwoch 2010; por. też Głosek 1984: kat. 264). Identycznie datowana jest też najbliższa terytorialnie analogia - odkryty zaledwie kilka kilometrów na wschód, już w obrębie ziemi sanockiej - miecz z okolic Jaślisk, pow. krośnieński (Kotowicz, Glinianowicz 20II). Nieco węziej - na drugą połowę XIV w. datowane jest inne małopolskie znalezisko - miecz wydobyty z dna Dunajca w Tropiu, pow. nowosądecki (Głosek 1984: kat. 32I), a także okazy odkryte: na dnie rzeki Ner w Bałdrzychowie, pow. poddębicki (Głosek 1984: kat. 226), w jeziorze Lednickim (Dziekanowice, pow. gnieźnieński) (Pudło, Żabiński 20II: 30-3I, kat. II, tabl. IX) oraz Warszawie, pow. loco (Głosek 1984: kat. 328). Ogólnie na XIV stulecie datowany jest natomiast okaz z Raciążka, pow. aleksandrowski (Głosek 1984: kat. 30I). Kilka okazów odkryto również na południe od ziem polskich. Wśród nich są datowane na drugą połowę XIV i początek XV stulecia miecze ze Słowacji - okaz przechowywany w Sarišskim Múzeum w Bardejovie (Głosek 1984: kat. 34, tabl. XXXIII:4; Aleksić 2007: kat. 20) i Muzeum Gemeru i Malohontu w Rimavskej Sobocie (Głosek 1984: kat. 105; Aleksić 2007: kat. 42). Nieco inaczej datowane są egzemplarze ze zbiorów czeskich. W ramach XIV w. umiejscowiony jest okaz z Muzeum města Brna (Głosek 1984: kat. 42; Hošek $\mathrm{i}$ in. 2019: kat. 278), a w drugiej połowie XIV - pierwszej połowie XV w. zabytek z Rožemberku (Národní památkový ústav - Státní hrad Rožemberk nad Vltavou) (Hošek i in. 2019: kat. 403). Pojedyncze okazy znane są też z Węgier - miecz odkryty na dnie rzeki Cisy w pobliżu Szolnok, XIV w. (Głosek 1984: kat. 442; Aleksić 2007: kat. 80), oraz Rumunii - okaz z miejscowości Curtea de Arges, druga połowa XIV - początek XV w. (Pinter 2007: Pl. 37:a; Aleksić 2007: kat. 156). Najwcześniej ze wszystkich tych analogii, gdyż na pierwszą połowę XIV stulecia, datowany jest okaz z Museum für Deutsche Geschichte w Berlinie (Głosek 1984: II5, kat. 195 - w tekście jego chronologię określono jednak na XIV w.).

Omówione wyżej znaki kowalskie w kształcie charakterystycznej litery „s” z szeryfami również występują w wyżej przedstawionych ramach chronologicznych. Jak wspomniano, na XIV w. datowany jest miecz ze zbiorów Muzeum Narodowego we Wrocławiu (Głosek 1984: 49, kat. 413, tabl. I:413), a na pierwszą połowę XV stulecia okaz wydobyty z fosy zamku w Ciechanowie (Małowiecki 1989: 130-134; Głosek 1996: 55-56). Nie odbiega od tego obrazu również datowanie jednego ze znaków zdobiących głownię miecza - rozwidlonego krzyża 
w podwójnym okręgu. Jak wykazano to wyżej, znaki takie występują głównie pomiędzy drugą połową XIV i pierwszą połową XV w., choć w pojedynczych przypadkach przeżywają się jeszcze w kolejnym pięćdziesięcioleciu (Aleksić 2007 : Cat. 269, Pl. 17:4).

Wszystkie te ustalenia pozwalają - naszym zdaniem - dość przekonująco umieścić miecz z Zyndranowej w okresie pomiędzy połową XIV i połową XV stulecia, z zastrzeżeniem, iż zapewne górną granicę tego przedziału należałoby zawęzić do początków XV w. Pozostaje jeszcze pytanie o miejsce pochodzenia tego miecza. Popularność formy wskazywałaby raczej na jakiś lokalny (Królestwo Polskie, Królestwo Węgier) warsztat, ale, posiłkując się ustaleniami badaczy dotyczącymi głowni zaopatrzonych $\mathrm{w}$ analogiczne znaki kowalskie, wydaje się też prawdopodobne, iż mógł on być wytworzony w warsztatach południowoniemieckich. Czy wszystkie trzy miecze (z Ciechanowa, Zyndranowej i ze zbiorów Muzeum Narodowego we Wrocławiu) sygnowane na trzpieniu znakiem w kształcie litery „„” w okręgu powstały w jednym ośrodku (por. ryc. 4)? Jest to trudne do jednoznacznego stwierdzenia - zwłaszcza, że w przypadku okazu ze zbiorów wrocławskich brak elementów oprawy rękojeści. Widać jednak ogólne podobieństwa w rozmiarach i proporcjach głowni wszystkich tych trzech okazów. Widać też pewne różnice, jak znacznie krótszy w stosunku do pozostałych trzpień rękojeści miecza z Zyndranowej. Być może wątpliwości te rozwieją przyszłe znaleziska.

Znalezisko miecza z Zyndranowej związane jest niewątpliwie z użytkowaniem szlaku komunikacyjno-handlowego prowadzącego w średniowieczu przez Przełęcz Dukielską. Niezbyt precyzyjne dane dotyczące okoliczności jego odkrycia nie pozwalają na rozważenie sytuacji, w jakiej mogło dojść do jego utraty przez właściciela. Warto jednak zauważyć, iż mamy tutaj do czynienia z kolejnym na terenie Polski znaleziskiem pochodzącym ze środowiska wodnego. Już M. Głosek zauważył, iż ponad 50\% mieczy datowanych od x po XV w. z terenu Europy Środkowej została wydobyta z wody, a nowsze odkrycia wyliczenia te potwierdzają. Fenomen ten jest trudny do wyjaśnienia, ale należy przyznać rację Arkadiuszowi Michalakowi, który zwrócił uwagę na fakt, iż nie zawsze musiała to być przypadkowa zguba w czasie przeprawy przez rzekę. Niekiedy należy wziąć również pod uwagę zachowania symboliczne, mające swe korzenie jeszcze w czasach przedchrześcijańskich (Michalak 20I5). Jak było z mieczem z Zyndranowej? Tego, niestety, zapewne już nigdy się nie dowiemy. 


\section{Bibliografia}

Aleksić M. (2007), Mediaeval Swords form Southeastern Europe. Material from ${ }_{12}{ }^{\text {th }}$ to Is ${ }^{\text {th }}$ century, Dedra, Belgrade.

Alexander D.G. (1985), European Swords in the Collections of Istanbul, part I, Swords from the Arsenal of Alexandria, „Waffen- und Kostümkunde. Zeitschrift für Gesellschaft für historische Waffen- und Kostümkunde", 2, s. 8I-II8.

Alexander D.G. (1987), European Swords in the Collections of Istanbul, part 2, „Waffenund Kostümkunde. Zeitschrift für Gesellschaft für historische Waffen- und Kostümkunde", I, s. 2I-48.

Anteins A. (1966), Im Ostbaltikum gefundene Schwerter mit damaszierten Klingen, „Waffen- und Kostümkunde. Zeitschrift der Gesellschaft für historische Waffen- und Kostümkunde", 2, s. III-I25.

Boeheim W.(1890), Handbuch der Waffenkunde, Verlag von E.A. Seemann, Leipzig.

Bordi Z.L.(2008), Középkori kardok a Székely Nemzeti Múzeum gyüjteményeiben, "Acta Siculica", s. 241-265.

Czajkowski J. (1995), Dzieje osadnictwa historycznego na Podkarpaciu i jego odzwierciedlenie w grupach etnograficznych, [w:] J. Czajkowski (red.), Eemkowie w historii i kulturze Karpat, wyd. II, Muzeum Budownictwa Ludowego w Sanoku, Sanok, s. 27-166.

Glinianowicz M., Kotowicz P.N.(2009), Dwa nieznane późnośredniowieczne miecze z potudniowo-wschodniej Polski, [w:] P. Kucypera, P. Pudło, G.Żabiński (red.), Arma et Medium Aevum, Wydawnictwo Adam Marszałek, Toruń, s. 182-197.

Głosek M. (1973a), Próba analizy znaków na mieczach średniowiecznych ze zbiorów polskich pod katem ich rodzimego pochodzenia, „Kwartalnik Historii Kultury Materialnej”, 21.2, s. 325-332.

Głosek M. (1973b), Znaki i napisy na mieczach średniowiecznych w Polsce, Zakład Narodowy im. Ossolińskich, Wrocław-Warszawa-Kraków-Gdańsk.

Głosek M. (1984), Miecze środkowoeuropejskie $z X-X V$ w. Wydawnictwa Geologiczne, Warszawa.

Głosek M.(1996), Późnośredniowieczna broń obuchowa w zbiorach polskich, Scientia - Naukowa Oficyna Wydawnicza, Warszawa-Łódź.

Głosek M., Kajzer L.(1976), Miecze z napisami grupy DIC w Europie Środkowej, „Kwartalnik Historii Kultury Materialnej”, 24.2, s. 217-248.

Głosek M., Nadolski A. (1970), Miecze średniowieczne z ziem polskich, Łódzkie Towarzystwo Naukowe, Łódź (Acta Archaeologica Lodziensia, 19).

Hošek J., Košta J., Žákovský P. (2019), Ninth to Mid-sixteenth Century Swords from the Czech Republic in their European Context, part I, The Finds, The Czech Academy of Sciences, Institute of Archaeology, Prague; The Czech Academy of Sciences, Institute of Archaeology, Brno; National Museum in Prague, Masaryk University in Brno, Prague-Brno.

Kotowicz P.N., Glinianowicz M. (2011), Późnośredniowieczny miecz z sygnowaną głowica zokolic Jaślisk w ziemi sanockiej, [w:] O. Ławrynowicz, J. Maik, P.A. Nowakowski 
(red.), Non Sensistis Gladios, Instytut Archeologii Uniwersytetu Łódzkiego, Łódź, s. $201-218$.

Krzyszowski A., Michalak A., Stępnik T. (2014), A Medieval Sword with Remains of a Scabbard Excavated in Buk in Greater Poland, „Acta Militaria Mediaevalia”, , s. $173-189$.

Kurtyka J. (1996), Potudniowy odcinek granicy polsko-ruskiej we wczesnym średniowieczu (przed 1340 r.) w świetle źródet historycznych, [w:] M. Parczewski, S. Czopek (red.), Początki sąsiedztwa. Pogranicze etniczne polsko-rusko-stowackie wśredniowieczu, Mitel, Rzeszów, s. 183-204.

Kuśnierz J.(2010), Wybrane militaria późnośredniowieczne w zbiorach muzeów i kolekcjach prywatnych potudniowej Lubelszczyzny, „Acta Militaria Mediaevalia”, 6, s.21I-232.

Liwoch R. (2006), Miecz ze Stogniowic, „Materiały Archeologiczne”, 36, s. 33-37.

Liwoch R.(2010), Późnośredniowieczne zabytki z Krakowa Rakowic, „Materiały Archeologiczne", 38 , s. I07-I26.

Madyda-Legutko R., Rodzińska-Nowak J., Zagórska-Telega J. (2007), Wyniki dalszych badań na cmentarzysku kultury przeworskiej w Prusieku stan. 25, pow. Sanok, „Rocznik Przemyski. Seria Archeologiczna”, 43.2, s. 6I-69.

Małowiecki R. (1989), Dwa miecze z Ciechanowa, „Zapiski Ciechanowskie”, 7, s. 130-I40.

Marek L. (2008), Broń biata na Ślasku XIV-XV wiek, Instytut Archeologii Uniwersytetu Wrocławskiego, Wrocław (Wratislavia Antiqua, io).

Marek L. (20I4), Europejski styl. Militaria z Elblaga i okolic, Wydawnictwo Uniwersytetu Wrocławskiego, Wrocław (Studia Archeologiczne, 47).

Marek L. (2017), Średniowieczne uzbrojenie Europy tacińskiej jako Ars Emblematica, Instytut Archeologii Uniwersytetu Wrocławskiego, Wrocław (Wratislavia Antiqua, 22).

Michalak A. (2007), „A grodzianie [...] wyszli naprzeciw z dobytymi mieczami...” Więcej o występowaniu mieczy na Środkowym Nadodrzu w średniowieczu, „Archeologia Środkowego Nadodrza", 5, s. 199-224.

Michalak A. (2015), Broń w wodnej toni. Uwagi o akwatycznych znaleziskach broni późnośredniowiecznej na marginesie odkryć z Lutola Mokrego, [w:] A. Jaszewska, A. Michalak (red.), Woda - zywiot ujarzmiony i nieujarzmiony, VII Polsko-Niemieckie Spotkania Archeologiczne, Materiaty z konferencji w Janowcu, 24-25 maja $2012 \mathrm{r}$., Stowarzyszenie Naukowe Archeologów Polskich Oddział Lubuski, Zielona Góra (Biblioteka Archeologii Środkowego Nadodrza, 8), s. 289-314.

Michalak A.(2019), Arma confinii. Przemiany późnośredniowiecznej broni na rubieżach Śląka, Wielkopolski, Brandenburgii i Łużyc, Muzeum Archeologiczne Środkowego Nadodrza, Zielona Góra.

Oakeshott R.E. (1964), The Sword in The Age of Chivalry, The Boydell Press, London.

Oakeshott R.E. (199I), Records of the Medieval Swords, The Boydell Press, Woodbridge.

Oakeshott R.E.(2000), Sword in Hand. A Brief Survey of the Knightly Sword, Arms \& Armor Inc.

Pinter Z.-K. (2007), Spada şi sabia medievală în Transilvania şi Banat (secolele IX-XIV), Ministerul Culturii şi Culterol, Muzeul Naţional Brukenthal, Sibiu (Bibliotheca Brukenthal, 7). 
Polakiewicz W. (1994), Miecz średniowieczny z Czorsztyna, ,Rocznik Podhalański”, 6, S. 42I-44I.

Pudło P., Żabiński G. (201I), Analiza formalna mieczy ze zbiorów Muzeum Pierwszych Piastów na Lednicy, [w:] A. Wyrwa, P. Sankiewicz, P. Pudło (red.), Miecze średniowieczne z Ostrowa Lednickiego i Giecza, Muzeum Pierwszych Piastów na Lednicy, Muzeum Pierwszych Piastów na Lednicy, Dziekanowice-Lednica (Biblioteka Studiów Lednickich, 3), s. 19-35.

Szope M. (1985), Miecze ze zbiorów Muzeum Okregowego w Tarnowie, „Tarnoviana”, s. $205-218$.

Zdaniewicz R. (2011), Dwie oktagonalne gtowice mieczy z terenu Górnego Ślaska, [w:] O. Ławrynowicz, J. Maik, P.A. Nowakowski (red.), Non Sensistis Gladios, Instytut Archeologii Uniwersytetu Łódzkiego, Łódź, s. 495-504.

Żabiński G. (2017), A Late Medieval Sword from River Wista near Gniew (Mewe) in Pomerelia, „Fasciculi Archaelogiae Historicae”, 30, s. I63-179, https://doi.org/10.23858/ FAH30.2017.014

Żabiński G., Stępiński J., Biborski M. (2014), Technology of Sword Blades from the La Tène Period to the Early Modern Age. The Case of what is now Poland, Archaeopress, Oxford, https://doi.org/I0.2307/j.ctvqmpi4Z

Žákovský P. (2008), Značené vrcholně a pozdnè stredověké dlouhé meče ze sbirek Městského muzea v Broumové, „Archaeologia Historica”, 33, s. 471-490.

Žákovský P. (20II), Zbraně a zbroj z pruni poloviny I4. století ve středni Evropè, [w:] D. Majer (red.), Král, který létal. Moravsko-slezsképomezi v kontextu stréedoevropského prostoru doby Jana Lucemburského, Ostravské museum, Ostrava, s. 84I-845.

\section{Summary}

The sword was discovered accidentally in the Panna River in the village of Zyndranowa (community Dukla, Podkarpackie voivodeship, south-eastern Poland). Currently, it is stored in the Castle Museum "Kamieniec" in Odrzykoń near Krosno (inv. no. M27/OI/K).

The sword from Zyndranowa is not fully preserved, probably about $20-25 \mathrm{~cm}$ of the blade in point part has been broken off and has not survived. Current dimensions of the sword: total length $-99.0 \mathrm{~cm}$; blade length $-76.0 \mathrm{~cm}$; width of the blade at the cross-guard $-5.6 \mathrm{~cm}$; length of the fuller $-49.5 \mathrm{~cm}$; length of the cross-guard $-22.5 \mathrm{~cm}$; height of the octagonal pommel $-4.3 \mathrm{~cm}$, pommel width of the pommel $-5.2 \mathrm{~cm}$, pommel thickness $-3.5 \mathrm{~cm}$, diameter of the oval recesses in the pommel $-1.3 \mathrm{~cm}$. The weight of the preserved part of the sword achieves $1328 \mathrm{~g}$.

The blade represents a type XVIa, the cross-guard type Ia and the pommel type $\mathrm{I}_{\mathbf{1}}$ according to R.E. Oakeshott typology.

There are three marks on the sword from Zyndranowa. On the one side of the grip shank there is an oval recess $(\mathrm{I} .0 \times \mathrm{I} .2 \mathrm{~cm})$ with raised letter " $\mathrm{s}$ " in the centre. It is most likely a sign of the blacksmith's workshop where the blade was made. On both sides of the blade, about $8.5 \mathrm{~cm}$ below the cross-guard, there are two different marks made by incrusting with non-ferrous metal. The first is the sign of the cross with split ends 
(cross fourchée), enclosed in a double circle. The second sign is much more difficult to determine. It resembles the Gothic letter A also enclosed in a double circle. However, it has an additional vertical bar in the middle, so it may be a combination of two letters AA or AR.

Swords such as the specimen from Zyndranowa (XVIa, II $\left.\left(\mathrm{I}_{\mathbf{1}} \mathbf{b}\right), \mathrm{I}_{\text {Ia }}\right)$ ) are popular forms among finds from Poland (about a dozen pieces in this type). There are also specimens with an S-shaped blacksmith's mark on the grip. The available analogies and typology of the sword discussed here allow us to establish the dating of it to the period between the mid-I $4^{\text {th }}$ and mid- $-5^{\text {th }}$ centuries (probably the narrowing down to the beginning of the $15^{\text {th }}$ century will be more adequate). Particularly noteworthy is the similarity to the sword from Ciechanów and the specimen from the collection of the National Museum in Wrocław (a similar typology and a sign with the letter "s"), perhaps they would have been made at the same workshop.

The place where the sword of Zyndranowa was found can be associated with the use of the communication and trade route running through the Dukielska Pass in the Middle Ages. It is another find of a medieval sword from the aquatic environment, which is very common in Poland - over 50\% of swords from the $10^{\text {th }}-15^{\text {th }}$ centuries were discovered in rivers and lakes.

Keywords: Kingdom of Poland, Little Poland, Dukielska Pass, Late medieval, sword, aquatic find

\section{Marcin Glinianowicz}

Muzeum Budownictwa Ludowego w Sanoku

e-mail: marcin.glinianowicz@gmail.com

\section{Piotr N. Kotowicz}

Muzeum Historyczne w Sanoku

e-mail: p_kotowicz@o2.pl 